\title{
Yabancı Uyruklu Öğrencilerin Sosyokültürel ve Akademik Uyumu Üzerinde Ulusal ve Örgütsel Kültürün Etkisi
}

\author{
Gökhan KARADİREK \\ Giresun Üniversitesi \\ gokhankaradirek_28@hotmail.com \\ ORCID ID: 0000-0002-0804-9904 \\ Mehmet Akif KARA \\ Giresun Üniversitesi \\ akifkara28@gmail.com \\ ORCID ID: 0000-0003-4308-9933
}

\begin{tabular}{lrr} 
Araştırma Makalesi & DOI: $10.31592 /$ aeusbed.808620 \\
\hline Geliş Tarihi: 10.10 .2020 & Revize Tarihi: 05.10 .2021 & Kabul Tarihi: 16.11 .2021
\end{tabular}

\section{Atıf Bilgisi}

Karadirek, G. ve Kara, M. A. (2021). Yabancı uyruklu öğrencilerin sosyokültürel ve akademik uyumu üzerinde ulusal ve örgütsel kültürün etkisi. Ahi Evran Üniversitesi Sosyal Bilimler Enstitüsü Dergisi, 7(3), 1046-1065.

\section{ÖZ}

$\mathrm{Bu}$ araştırmanın amacı, yabancı uyruklu üniversite öğrencilerinin sosyokültürel ve akademik uyumu üzerinde ulusal ve örgütsel kültürün etkisini ortaya koymaktır. Verilerin toplanmasında Hsu (2011) tarafından geliştirilen bir ölçek kullanılmıştır. Veri toplama, 24 Nisan 2020-18 Mayıs 2020 tarihleri arasında online anket tekniği ile gerçekleştirilmiştir. Araştırmanın evreni Giresun Üniversitesindeki yabancı uyruklu öğrencilerdir. Araştırmanın örneklemini anketi yanıtlayan 345 yabancı uyruklu öğrenci oluşturmaktadır. Veriler, SPSS 25 istatistik yazılımı ile analiz edilmiştir. Öncelikle veriler üzerinde normallik testi, güvenirlik ve faktör analizi yapılmıştır. Hipotezler, korelasyon ve regresyon analizi yöntemi kullanılarak test edilmiştir. Araştırma sonucunda; yabancı uyruklu öğrencilerin sosyokültürel uyumu üzerinde motivasyonun, etkileşimin, öğretim elemanı algısının ve ekonomik sorunların etkili olduğu bulunmuştur. Akademik uyum üzerinde ise motivasyonun ve öğretim elamanı algısının etkisi tespit edilmiştir. Türkçe konuşma rahatlı̆̆ının hem sosyokültürel hem de akademik uyum üzerinde bir etkisi bulunamamıştır. Ayrıca, akademik uyumun üzerinde ekonomik sorunların ve etkileşimin de etkisinin olmadığı sonucuna ulaşılmıştır. Bu araştırmanın bulgularına göre, yabancı uyruklu öğrencilerin sosyokültürel ve akademik uyumunda, motivasyon ve öğretim elemanı algısı önemli bir belirleyicidir. Ayrıca, sosyokültürel uyum konusunda etkileşim ve ekonomik sorunların da önem arz etmektedir. Bu kapsamda üniversiteler, yabanc1 uyruklu öğrencilerin eğitim-öğretimi boyunca onların memnuniyetini sağlamayacak desteklerde bulunmalıdır.

Anahtar Kelimeler: Sosyokültürel uyum, akademik uyum, yabancı uyruklu öğrenci, öğretim elemanı algısı, motivasyon.

\section{The Effect of National and Organizational Culture on Sociocultural and Academic Adaptation of Foreign Nationality Students}

\begin{abstract}
The aim of this study is to reveal the effect of national and organizational culture on the sociocultural and academic adaptation of foreign university students. A scale developed by Hsu (2011) was used to collect the data. Data collection was carried out between 24 April 2020 and 18 May 2020 with the online survey technique. The sample of the study consists of 345 foreign students from Giresun University. Data were analyzed with SPSS 25 statistical software. First, normality test, reliability and factor analysis were performed on the data. Hypotheses have been tested using correlation and regression analysis method. As a result of the research, it was found that motivation, interaction, perception of instructor and economic problems are effective on the sociocultural compatibility of foreign nationality students. On the other hand, the effect of motivation and the perception of the instructor on academic adaptation was determined. The comfort of speaking Turkish did not have an effect in both socio cultural and academic adaptation. According to the findings of this study, motivation and perception of instructors are important determinants of the sociocultural and academic adaptation of foreign students. In addition, interaction and economic problems are important in sociocultural adaptation. In this context, universities should provide support to foreign students to ensure their satisfaction during their education.
\end{abstract}

Keywords: Sociocultural adaptation, academic adaptation, foreign nationality student, instructor perception, motivation. 


\section{Giriş}

Küreselleşme süreci ile birlikte göç hareketleri gün geçtikçe giderek artmakta ve ülkeler arasında mobilite hızlanmaktadır. Türkiye'de özellikle 1980'lerden sonra "göç ülkesi" haline gelmiş ve göçmenler için hedef ülke halini almaktadır (Kara, 2017). Aynı zamanda Türkiye'deki üniversitelerin yoğunluğu ve akademik başarısı nedeniyle yabancı öğrencilerin tercih ettiği bir ülke olmaktadır. Yine, özellikle soydaşlıktan ötürü Türki Cumhuriyetlerden bir çok öğrenci okumak amacıyla Türkiye'ye göç etmektedir. Üniversitelerin, Erasmus başta olmak üzere çeşitli projelerle yabanc1 öğrenciler ile etkileşim kurmaları, Türkçe Öğretim Merkezi (TÖMER) vasıtasıyla Türkçe öğretimi üzerine yoğunlaşılması gibi bir çok faktör de yabancı öğrencileri Türkiye'ye çekmektedir.

Ulusların kültürel özellikleri, yaşam biçimleri, örgütlenme şekilleri bireysel ve örgütsel başarıları etkileyebilmektedir. Özellikle üniversiteler, ulusal kültürün yoğun olarak temsil edildiği, ulusal ve uluslararası kültür özelliklerinin sergilendiği örgütlerdendir. Çünkü üniversiteler, farklı kültürlerden çok sayıda öğrencinin akademik eğitimini sürdürmek istediği yükseköğretim kurumlarıdır. Bu eğitim sürecinde öğrencilerin sosyokültürel ve akademik uyumunu etkileyebilen bazı faktörlerin ortaya çıması da doğaldır. Üniversite öncesindeki eğitim, genellikle bireyin aileyle, yakın aile çevresinde ve insanların ortak kültürü paylaştığı biraz daha dar çevrede gerçekleşmetedir. Yükseköğretim öncesi eğitime göre akademik eğitim, ulusal ve uluslararası ölçekte daha fazla kültürel özelliği bir araya getirebilmektedir. Bilhassa yabanc1 uyruklu öğrencilerin fazla olduğu yükseköğretim örgütlerinde öğrencilerin sosyokültürel ve akademik uyumunu etkileyebilen yeni sorunların ortaya çıkması daha muhtemeldir. Dahası yabanc1 uyruklu öğrencilerin uyum problemi yaşaması kültürlerarası farklılığın büyüklüğ̈̈ ile oranlıtı olabilir. Başka bir ifadeyle kültürlerarası farklılık arttıkça yabancı uyruklu öğrencilerin sosyokültürel ve akademik uyum gibi bazı uyum problemleriyle karşılaşması da kolaylaştırabilir.

Başka ülkelerdeki yabancı uyruklu öğrenciler gibi Türkiye'deki yabancı uyruklu öğrenciler de üniversite eğitimi süreciyle birlikte uluslararası ve örgütsel düzeyde benzer ya da yeni uyum problemleri yaşayabilmektedir. Örneğin; dil öğrenme süreci ve uyumu, yaşam biçimi, yemek, giyim, barınma, insan ilişkileri (ön yargı, dışlama, üniversitedeki idari ve akademik personel), şehrin hoşuna gitmemesi, gelenek ve görenek, ev özlemleri, pahalılık gibi ekonomik problemler, aileye duyulan özlem, iklim koşulları gibi ulusal, örgütsel ve çevresel özellikler yabancı uyruklu öğrencilerin sosyokültürel ve akademik uyumunda belirleyici faktörler olarak gösterilebilir. Türkiye'deki yabancı uyruklu öğrenciler açısından bu tür faktörlerin etkisini ulusal alandan bölgesel ve örgütsel alana indirgemek, ele almak ve değerlendirmek önemli olabilir. Çünkü yabancı uyruklu öğrencilerin sosyokültürel ve akademik uyum problemiyle ilgli daha özel bulgulara ulaşmak, bu öğrencilerin akademik eğitimini kolaylaştırıcı ve başarısını destekleyici adımların atılmasına öncülük edebilir. yardımcı olabilir. Bazı araştırmalar, yabancı uyruklu öğrencilerin başarıları olabilmesi için desteğe ihtiyaç duyduklarını belirtmektedir. Türki Cumhuriyetlerden akademik eğitimi almak için Türkiye'ye gelen öğrencilerin büyük bir kısmı akademik süreçlerini sonuçlandıramamaktadır. Yani mezun olamamaktadır. Örneğin; Azerbaycan, Kazakistan, Türkmenistan, Kırgızistan, Tacikistan gibi ülkelerden gelen çoğu öğrencinin mezuniyet seviyesine ulaşamadığ 1 ifade edilmektedir (Özkan ve Acar Güvendir, 2015). Bu nedenle yabanc1 uyruklu öğrencilere destek olmak, bu öğrencilerin sosyokültürel, örgütsel ve akademik uyum ile ilgili yaşadıkları olumsuzlukların etkisini tamamen ortadan kaldırmak ya da en aza indirmek, Türkiyedeki yabancı uyruklu öğrencilerin sosyokültürel, örgütsel ve akademik eğitim hayatında tatmin yaşamalarını kolaylaştırabilir. Tatmin olmuş bu öğrenciler, diğer öğrencilerin ülke ve üniversite tercihi için referans olabilir. Türkiyede, Giresun Üniversitesi yabanc1 uyruklu öğrenci sayısı bakımından önemli bir yere sahiptir. Giresun Üniversitesinde kayıtlı yaklaşık bin kadar yabancı uyruklu öğrenci bulunmaktadır. Bu öğrencilerin çoğunluğunu Türki Cumhuriyetlerden gelen öğrenciler oluşturmaktadır. Türkiyedeki diğer üniversitelerin sahip olduğu yabancı uyruklu öğrenci sayısıyla kiyaslandığında da Giresun Üniversitesindeki yabancı uyruklu öğrenci sayısının oldukça yüksek sayıda olduğu söylenebilir.

Bu çalışma için yabancı uyruklu öğrenci sayısı ve öğrencilerinin niteliği göz önüne alındığında Giresun Üniversitesi, yanabcı uyruklu öğrencilerin sosyokültürel ve akademik uyumunda ulusal ve 
örgütsel kültürün etkisini ortaya koyabilme amacına uygun ve kabul edilebilir bir araştırma sahası olarak belirlenmeiştir. Bu kapsamda, yabancı uyruklu öğrencilerin akademik eğitimi sürecinde sosyokültürel ve akademik uyum sağlamasına engel olabilecek bazı temel problemlerin belirlenmesi amaçlanmıştır. Bu temel problemlerin öğrencilerin sosyokültürel ve akademik uyumu ile arasındaki ilişkiyi ortaya koyabilmek istenmiştir. Böylece Türkiyedeki yabancı uyruklu öğrencilerin yaşaması muhtemel sosyokültürel ve akademik adaptasyon problemine kolay ve daha hızlı çözüm sağlayacak önerilerin geliştirilebileceği öngörülmüştür. Ayrıca bu çalışma yabancı uyruklu öğrencilerin Türkiye'de eğitimini devam ettirirken yaşadıkları problemler konusunda farkındalık yaratabileceği vaysayılmıştır. $\mathrm{Bu}$ çalışmanın varsayımları çerçevesinde yabancı uyruklu öğrencilerle ilgili sosyokültürel ve akademik uyumu, motivasyon, Türkçe konuşma rakatlı̆̆ı, ekonomik sorunlar, etkileşim ve öğretim elemanı algısı kavramları ele alınmıştır.

$\mathrm{Bu}$ çalışmayı önceki araştırmalardan farklı kılan bazı özellikler bulunmaktadır. Çalışma, amacı, konunun ele alınışı ve içeriği, araştırmada kullanılan değişkenleri ve ortaya konulmak istenen model bakımından diğer çalışmalardan farklılaştığı düşünülmektedir. Bu çalışma, başta Giresun Üniversitesi olmak üzere ulusal, uluslararası ve bölgesel düzeydeki bilgi kullanıcılarına; yabancı uyruklu öğrencilerin sosyokültürel ve akademik uyumu ile motivasyonu, etkileşimi, Türkçe konuşma rahatlığı, öğretim elemanı algısı, ekonomik sorunları arasındaki ilişki hakkında birtakım bilgiler sunmaktadır. Bilgi kullanıcıları, analiz edilmiş ve paylaşılmış bilgilerden (örneğin, demografik bilgiler) hareketle ayrıca çıkarımlarda bulunabilirler.

Sosyokültürel ve akademik uyumla ilgili bilgilerin öncesinde "uyum" kavramını kısaca açıklamak daha anlamlı ve faydalı olabilir. Uyum, karmaşa, stres, belirsizlik gibi zor koşullarda gereken esnekliği gösterebilmeyi ifade eden, insanların sosyal ve iş çevrelerindeki değişimlere kendisini ayarlmabilme yeteneğidir. Uyum, başarılı olabilmenin temel faktörlerindendir (Üstün ve Büyükbaş, 2020). Sosyokültürel uyum, bireyin yeni sosyokültürel bir ortamda etkin bir şekilde hayatını sürdürmesi için temel kültürün belli kültürel özelliklerini ne kadar başarılı bir şekilde benimsediğini ve kullanabildiğini ifade etmektedir (Berry, Poortinga, Breugelmans, Chasiotis ve Sam, 2011). Sosyokültürel uyum olgusu, bireyin baskın kültürdeki insanlarla başarılı bir biçimde etkileşim kurabilmesine odaklanmaktadır (Şeker ve Akman, 2016). Bir bireyin okulda veya işteki günlük yaşamlarında ne kadar iyi bir şekilde görevlerini yerine getirebileceği sosyokültürel uyumla açıklanmaktadır. Bu nedenle sosyokültürel uyum genelde bireylerin toplumsal olarak fonksiyonlarını yerine getirilebilmesiyle ilişkilendirilmektedir. Örneğin, sosyokültürel uyum ergenlerin akademik performansını etkileyebildiği ileri sürülmektedir (Berry ve Sabatier, 2010). Benzer şekilde bu çalışmada, sosyokültürel uyumun, özellikle uluslararası düzeyde faaliyet gösteren organizasyonlardaki bireylerin örgütsel ve kişisel başarısında önemli bir yere sahip olacağı varsayılarak akademik eğitim sürecinde yabancı uyruklu öğrencilerin sosyokültürel uyumu araştırılmaktadır. $\mathrm{Bu}$ çalışmada sosyokültürel uyum kavramı, yabancı uyruklu öğrencilerin akademik eğitimini sürdürdüğü ülkedeki yeni sosyokültürel ortamla ilgili adaptasyon seviyesini ifade etmektedir. Bu adaptasyon, öğrencilerin kendi kültürel geçmişiyle ve yeni sosyokültürel özelliklerin benimsenmesi düzeyi ile ilgilidir (Hsu, 2011). Yabancı uyruklu öğrencilerin üniversite süreçlerinde karşı karşıya kaldıkları bazı problemler, sosyokültürel uyumla ilişkilendirilebilmektedir. $\mathrm{Bu}$ problemler, öğrencilerin sosyokültürel uyumundaki belirleyiciler olarak gösterilmektedir. Örneğin, gelenek-görenek, insan ilişkileri, giyim, yemek kültürü, barınma koşulları (Kıroğlu, Kesten ve Elma, 2010) gibi ulusal, bölgesel veya şehir kültürü özelliği yabancı uyruklu öğrencilerin sosyokültürel uyumunu etkileyebilmektedir. Dolayısıyla da sosyokültürel, ekonomik ve politik, eğitim geçmişi, tecrübe gibi farklılıklar, öğrencilerin sosyokültürel uyumuna ve akademik başarısına yansıyabilmektedir. Yabancı uyruklu bir öğrencinin akademik anlamda başarıya ulaşabilmesinde, eğitimini devam ettirdiği ülkenin veya ulusun kültürü ile hayat tarzının uyumu önemlidir (Başaran Alagöz ve Geçkil, 2017). Başka bir ifadeyle akademik başarıda, öğrencilerin sosyokültürel adaptasyonu belirleyici bir faktör olabilir. Ayrıca, yabancı uyruklu öğrencilerin akademik eğitimdeki geçirdikleri süre de sosyokültürel uyumu olumlu etkileyebilmektedir. Sınıf düzeyi yükseldikçe yabancı uyruklu öğrencilerin sosyokültürel problemleri azabilmektedir. Öğrenciler bir üst sınıfa yükseldikçe, öğrencilerin sosyal etkinliklere katılımı kolaylaştırmakta ve yabancı dil yeterlilikleri zamanla daha iyi duruma gelebilmektedir (Kumcağız, Dadashzadeh ve Alakuş, 2016). 
Akademik uyum, yabancı uyruklu öğrencilerin üniversitedeki eğitimi ve başarısıyla ilgili bir adaptasyon sorunu olduğu söylenebilir. Çünkü dersi anlama düzeyi yabancı uyruklu öğrencilerin akademik eğitimi sürecinde yaşadığı temel problemler arasında bulunmaktadır (Özkan ve Acar Güvendir, 2015). Yine yabancı uyruklu öğrencilerin akademik ortama uyum süreci öğrencilerin yaşadığı stresi, öğretme ve öğrenme algılarını doğrudan etkileyebilmektedir (Yang, 2006). Dolayısıyla yabanc1 uyruklu öğrencilerin akademik eğitimden tatmin olabilmesi için akademik uyum sorununu gidermek temel önceliklerden kabul edilmelidir. Yabancı uyruklu öğrencilerin adaptasyonunu sağlayabilmek ve memnuniyet düzeylerinin sürdürülebilir kılmak amacıyla öğrencilerin akademik ve sosyal hayatını olumlu etkileyecek merkezler kurulabilir (Özkan ve Acar Güvendir, 2015). Yabanc1 uyruklu öğrencilerin sosyokültürel ve akademik uyumu kültürleşme kuramıyla ilişkilendirilebilir. Sosyokültürel değişikliklerin insanların davranışları üzerinde ortaya çıkardığı etkiyi araştırmak, anlamaya çalışmak kültürleșme kuramının bir parçası olarak görülmektedir (Güngör, 2014). Kültürleşmenin sonuçları sosyokültürel uyumu, öğrencinin okul başarısını etkileyebilmektedir Çünkü Sosyokültürel uyum, kültürleşme uyumunun bir bileşenleri olarak kabul edilmektedir (Ward, 1996). Sosyokültürel uyum, öğrencilerin stres yaşamalarıyla, öğrenme ve öğrenme algılarıyla ilişkili olduğundan(Yang, 2006) yabancı öğrencilerin en önemli sorunları arasında görülmektedir. Hsu (2011) yabancı uyruklu öğrencilerin akademik ve sosyokültürel uyumlarını etkileyen faktörleri Dönüşümsel Öğrenme Kuramıyla ve sosyoloji, psikoloji teorilerinden yararlanarak açıklamaya çalışmaktadır.

Motivasyon, "istekleri, arzuları, ihtiyaçları, dürtüleri ve ilgileri kapsayan genel bir kavram"dır (Cüceloğlu, 2005). Motivasyon öğrenmeyle ilgili bir güdüdür ve bir hedefe doğru davranışı harekete geçiren, davranışı yönlendiren bir güçtür. Motivasyonun bir eylemi başlatabilme ve sürdürebilme gücünün olması nedeniyle motivasyon, başarıyı ve verimliliği belirleyebilen bir olgu olarak görülmektedir (Dilekmen ve Ada, 2005). Dolayısıyla istekler, arzular, ihtiyaçlar ve dürtüler diğer bireylerde olduğu gibi öğrencilerde bazı davranışları ve tutumları ortaya çıkarabilir. Motivasyonla ortaya çıkan davranışlar ve tutumlar ise öğrencinin başarısını ve verimliliğini etkileyebilir. Öğrencilerin eğitim sürecini şekillendirebilir. Motivasyon veya güdü diğer hayat planlamalarında olduğu gibi öğrencilerin eğitim sürecinde de ortaya çıkabilir. Hatta öğrenciler başka ülkelerde eğitim almaya motive olabilir. Çünkü öğrencileri başka bir ülkede eğitim görmeye motive eden bazı faktörler söz konusudur. Türkiye'de yapılan bir araştırmaya göre Türk öğrencileri yabancı bir ülkede eğitim almaya motive eden şeylerden biri Türkiye'de eğitim almakta olduğu üniversitenin kültürüdür (Rüzgar, 2020). Rüzgar (2020) göre ailenin özendirmesi, öğrencinin çalışmak istediği alanda Türkiye'de programının bulunmaması, daha nitelikli bir üniversite görme amacı, yurt dışı görme ve göç etme arzusu gibi faktörler de öğrencileri güdüleyici olabilmektedir. Benzer şekilde yükseköğretimdeki kültür, öğrencilerin motivasyonunu, yaşantısını verimlilik, karar verme ve örgüt içindeki iletişimi etkileyebilmektedir (Gizir, 2007). Bu çalışma ile Giresun Üniversitesindeki yabanc1 uyruklu öğrencilerin motivasyonları ile akademik ve sosyokültürel uyumu arasındaki ilişki ortaya konulmak istenmiş ve aşağıdaki hipotezler geliştirilmiştir.

Hipotez 1: Yabancı uyruklu öğrencilerin sosyokültürel uyumu üzerinde yurt dışında okuma isteğiyle ilgili motivasyonun pozitif etkisi vardır.

Hipotez 2: Yabancı uyruklu öğrencilerin akademik uyumu üzerinde yurt dışında okuma isteğiyle ilgili motivasyonun pozitif etkisi vardır.

Etkileşim düzeyi, bir arada yaşamayı zorlaştıran olumsuzlukların ortadan kaldırılmasına yardımcı olabilmektedir. Farklı etnik kökene veya kültüre ait bireylerin ya da alt kültür üyelerinin kültürlerarası iletişimi bir etkileşimin sonucunda meydana gelmektedir (Özdemir, 2011). Literatürde, etkileşim ile sosyokültürel uyum arasında olumlu bir ilişkinin olduğu yönünde çıkarım yapılabilecek açıklamalar bulunmaktadır (Saygın ve Hasta, 2018). Saygın ve Hasta'ya (2018) göre etkileşim, insanların eğitim ve iş hayatındaki uyumu kolaylaştırabilmektedir. Ayrıca, herhangi bir toplumda, azınlıklar dahil herkesin ortak bir dili konuşması da etkileşimi, sosyal ilişkileri ve uyumu kolaylaştırmaktadır (Ward ve Kennedy, 1992). Ayrıca insanlar, başka bir ülkenin kültürel özelliklerini öğrenerek yabancı ülkeye kolayca uyum sağlayabilirler. Diğer insanlarla hayatı rahatça paylaşabilirler ve rahatça çalışabilirler (Temel Eğinli, 2011). Bazı araştırmalarda, başka ülkelerde olumlu etkileşimde 
bulunmak ve bireylerle ilişkileri güçlendirmek gerektiği vurgulamaktadır (Ward ve Rana-Deuba, 2000). Ward ve Rana-Deuba (2000) göre kültürel olarak azınlığa sahip bireylerin ana kültürün üyeleri ile kurduğu etkileşim düzeyi arttıkça kültürel azınlıktaki bireylerin sosyokültürel uyum seviyesi yükselmekte ve sosyokültürel uyum konusunda daha az problem yaşamaktadır. Aksi durumda ise etkileşim düzeyi azaldıkça sosyokültürel uyumla ilgili sorunlar da artmaktadır. Etkileşim, iletişimsel sonucu, etkileşimin gücünü ise iletişimin niteliğini belirleyebilir. Örneğin yabancı uyruklu öğrencilerin bulunduğu ortamlarda, iletişimde yaşanabilecek olumsuzluklar, öğrencilerin akademik başarısında azalmanın ve soru sorma gibi konulardaki eksikliğin bir nedeni olarak görülmektedir (Kumcă̆ız vd., 2016). Alan yazındaki bilgilerden hareketle bu çalışmada etkileşim ile sosyokültürel ve akademik uyumu arasındaki ilişkinin belirlenmesi istenmektedir. İlişkilerin belirlenmesi amacıyla geliştirilen iki hipotez aşağıdaki gibidir.

Hipotez 3: Yabanc1 uyruklu öğrencilerin sosyokültürel uyumu üzerinde etkileşin pozitif etkisi vardir.

Hipotez 4: Yabancı uyruklu öğrencilerin akademik uyumu üzerinde etkileşimin pozitif etkisi vardir.

Eğitimcilerin öğrenciler tarafından nasıl algılandığını bilmek öğrencilerin eğitimle ilgli duygularını anlamamıza yardımcı olabilir. Eğitim örgütünde görevli eğitimcilerin öğrenciler tarafından olumlu algılanması, tüm düzeylerdeki öğrencilerin örgütsel uyumunu, eğitime devam etmeye yönelik arzusunu ve örgütten ve eğitimden aldığı memnuniyeti etkileyebilir. Bu konu, akademik düzeyde eğitim alan yabancı uyruklu öğrenciler açısından ele alınarak, yabancı uyruklu öğrencilerin öğretim elemanı algısı, akademik ve örgütsel uyumu hakkında bilgi sahibi olunabilir. Bu öğrencilerin özellikle öğretim elemanı algısı, öğrencilerin akademik ve örgütsel uyumuna katkı sağlayabilir. Bu çalışmada öğretim elemanı algısı, öğrencilerin iletişimde ve etkileşimde bulundukları eğitimcileri nasıl algıladıklarını ifade eden bir kavram olarak kullanılmaktadır. Bu kavram, bir öğretim elemanı hakkında olumlu veya olumsuz değerlendirme yapabilmeye imkân tanıyan birçok ölçüte sahiptir (Hsu, 2011). Hsu (2011) çalışmasında, dersle ilgili materyallerin paylaşılması, öğrencinin bölümüyle ilgili teorik ve uygulamalı mesleki bilgi paylaşımı, dersle ilgili ödevlere yönelik açıklayıcı geri bildirimlerde bulunmak, öğrencilerin başarılı (kaliteli) çalışmalarını motive eden konuşmalar yapmak, öğrencilerin dersle ilgili yorumlarını önemsemek ve öğrenmeye teşvik eden sorular sormak, öğrencileri anlamaya yardımcı olmak ve akademisyenin derste esprili olup olmaması ve tecrübelerini öğrencilerle paylaşması, eğitimcinin ders dışı konuşmalarda bulunması gibi konular birer ölçüt kabul edilerek öğrencilerin öğretim elemanı algısının ölçülebileceği düşünmektedir. Hsu (2011) göre öğretim elemanı algısı ile akademik ve sosyokültürel uyum arasında pozitif ilişki bulunmaktadır. Literatürdeki çalışmalardan hareketle bu çalışma için şu hipotezler ileri sürülmektedir.

Hipotez 5: Yabanc1 uyruklu öğrencilerin sosyokültürel uyumu üzerinde öğretim elemanı algısının pozitif etkisi vardır.

Hipotez 6: Yabancı uyruklu öğrencilerin akademik uyumu üzerinde öğretim elemanı algısının pozitif etkisi vardır.

Başka bir ülkede eğitim alan öğrencilerin eğitim aldıkları ülkenin ana diliyle kolayca iletişim kurabilmesi yabanc1 uyruklu öğrencilere eğitimi boyunca avantaj sağlayabilir. Başka ülkelerden akademik eğitim için gelen öğrencilerin Türkçeyi rahatça konuşabilmesi Türkiye'deki akademik eğitimini kolaylaştırabilir. Türkiye'deki öğrencilerin eğitimini kolaylaştırmak amacıyla özellikle temel eğitimleri öncesinde Türkçe eğitimi verilmektedir. Türkiye'de yabancı uyruklu üniversite öğrencilerinin Türkçeyi öğrenebilmesi ve rahatça konuşabilmesi amacıyla bazı Üniversitelerde Türkçe öğretimi verilmektedir. Üniversitelerde bu eğitim, TÖMER tarafından yürütülmektedir (Ünal, Taşkaya ve Ersoy, 2018). Yabancı uyruklu öğrencilerin iletişim kurabilmesini kolaylaştırmak için Türkçe dil öğrenme süreci halen Türkiye'de 1980'li yıllarda faaliyete başlayan TÖMER ve Yunus Emre Enstitüleri tarafindan yürütülmektedir (Mete, 2015). Bu eğitim ile yabanc1 uyruklu öğrencilerin akademik eğitim sürecinde rahatça iletişim kurabilmelerini sağlamak ve kültürel yönden 
adaptasyonlarını kolaylaştırmak amaçlanmaktadır. Araştırmalarda Türkçeyi anlamak, yabancı uyruklu öğrencilerin önemli bir problemi olduğu belirtilmektedir. Türk dünyasından gelen öğrencilerin dahi Türkiye Türkçesi konuşmalarının iyileştirilmesi gerektiği belirtilmektedir. Bu dil konusunun yabanc1 uyruklu öğrencilerde bir sorun oluşturduğu vurgulanmaktadır (Özkan ve Acar Güvendir, 2015, s. 180). Ward ve Kennedy (1993), yabanc1 uyruklu öğrencilerin sosyokültürel uyumunda yaşamsal değişikliklerin, dil yeterliliğinin, kültürel kimliğin ve mesafenin (kültürel bütünleşme-ayrılık), ev sahibi ülkedeki bireylerle ve ailelerle kurulan iletişimden tatmin olmanın, ev sahibi ülkeye yönelik tutumlarının etkili olduğunu ileri sürmektedir. Yabancı uyruklu öğrenciler, sosyokültürel uyum konusunda diğer öğrencilere göre daha fazla zorluk yaşayabilmektedir. Bu çalışmada, yabancı uyruklu öğrencilerin sosyokültürel ve akademik uyumu ile Türkçe konuşma rahatlığı arasındaki ilişki ele alınmaktadır. Değişkenlerin aralarındaki ilişkilerin sınamak amacıyla iki hipotez geliştirilmiştir.

Hipotez 7: Yabanc1 uyruklu öğrencilerin sosyokültürel uyumu üzerinde Türkçe konuşma rahatlığının pozitif etkisi vardır.

Hipotez 8: Yabancı uyruklu öğrencilerin akademik uyumu üzerinde Türkçe konuşma rahatlığının pozitif etkisi vardır.

Ekonomik sorunlar, bireylerin ve örgüt hayatının temel problemlerindendir. Bireysel düzeyde ekonomik sorunlara en fazla maruz kalan ve bu sorunların kişisel olarak etkilerini hisseden gruplardan biri Üniversite öğrencileridir.

Ekonomik sorunların boyutu, üniversite öğrencilerinin ulusal ve uluslararası eğitimlerine göre farkl1lık gösterebilir. Bu sorunlar özellikle yabanc1 uyruklu öğrencilerin eğitim-öğretim süreçlerini doğrudan ya da dolaylı olarak daha fazla etkileyebilir. Kıroğlu ve diğerleri (2010), yabancı uyruklu öğrencilerin hareketliliği dünya genelinde dil ve eğitim sorunlarına neden olduğu gibi ekonomik ve sosyokültürel problemleri de ortaya çıkarmaktadır. Türkiye'deki yabancı uyruklu üniversite öğrencilerinin de akademik eğitimi boyunca yaşadığ temel problemlerden biri ekonomik sorunlardır (Özkan ve Acar Güvendir, 2015). Barınma yeri gibi faktörler dolaylı olarak yabancı uyruklu öğrencilerin ekonomik sorunlarına neden olabilmektedir. Örneğin kamuya ait konaklama yerleri veya yurtlarla ilgili kontenjanların yetersizliği, özel yurtların öğrenci için yüksek maliyet arz etmesi özellikle sosyo-ekonomik bakımdan zayıf yabancı uyruklu öğrencileri olumsuz etkileyebilmektedir. $\mathrm{Bu}$ durum aynı ülkeden gelen öğrencilerin daha fazla birlikte kalmasına neden olduğu gibi hem hedef kültürün tanınmasına hem de öğrenilmesine engel olabilmektedir (Kumcağız vd., 2016). Bu çalışmada da yabancı uyruklu üniversite öğrencilerin ekonomik sorunları önemsenmektedir. Yabanc1 uyruklu öğrencilerin sosyokültürel ve akademik uyumu ile ekonomik sorunları arasındaki ilişkiyi açıklayabilmek amacıyla aşağıdaki varsayımlar geliştirilmiştir.

Hipotez 9: Yabancı uyruklu öğrencilerin sosyokültürel uyumu üzerinde ekonomik sorunların negatif etkisi vardır.

Hipotez 10: Yabancı uyruklu öğrencilerin akademik uyumu üzerinde ekonomik sorunların negatif etkisi vardır.

Araştırmanın temel amacı, yabancı uyruklu üniversite öğrencilerinin sosyokültürel ve akademik uyumu üzerinde ulusal ve örgütsel kültürün etkisini belirlemektir. Araştırma, Giresun Üniversitesinde aktif olarak kaydı bulunan, lisans ve ön lisans düzeyinde öğrenim gören 345 yabancı uyruklu öğrencinin saha araştırmasının yapıldığı tarihte sosyokültürel ve akademik uyum, motivasyon, etkileşim, Türkçe konuşma rahatlığı, öğretim elemanı algısı, ekonomik sorunlar faktörleriyle ilgili görüşleriyle ve değişkenler arasındaki ilişkilerin incelenmesiyle sınırlıdır. Araştırmada kullanılan değişkenlerin sınırlandırılmasında ise önceki araştırmaların sonuçları; ortak faktörler veya faktörün yüzdelik oranı, değişkenlerin aralarındaki ilişkisi birer kıstas olmuştur. Bu araştırma, Türkiye'deki yabancı uyruklu öğrencilerin kültürel ve örgütsel uyumları üzerinde, çalışmada kullanılan değişkenler çerçevesinde, hangi faktörlerin etkili olduğunun belirlenmesi açısından önemlidir. $\mathrm{Bu}$ araştırmada kullanılan değişkenler, Türkiye'de bu alanda yapılmış diğer çalışmalardan farklılaştırmakta, 
araştırmayı özgünleştirmektedir. Ayrıca araştırmanın bulguları, Türkiye'deki üniversitelerde eğitim gören yabanc1 uyruklu öğrencilerin sosyokültürel ve akademik uyumunu artırabilecek bilgiler sunması nedeniyle bu alandaki boşluğun doldurulmasına katkı sağlamaktadır.

\section{Yöntem}

$\mathrm{Bu}$ bölümde, veri toplama aracının oluşturulması, evren ve örneklem, saha araştırmasının sonucunda elde edilen veriler ve verilerin analiziyle ilgili bilgiler açıklanmıştır.

\section{Araştırma Modeli}

$\mathrm{Bu}$ çalışma, nicel araştırma deseninde, ilişkisel tarama modeli kullanılarak gerçekleştirilmiştir. İlişkisel tarama modeli çerçevesinde yabancı uyruklu üniversite öğrencilerinin sosyokültürel ve akademik uyumu ile motivasyon, etkileşim, Türkçe konuşma rahatlığı, öğretim elemanı algısı, ekonomik sorunları arasındaki ilişki ortaya konulmuştur. Yabancı uyruklu öğrencilerin sosyokültürel ve akademik uyumu üzerinde ulusal ve örgütsel kültürün etkisini belirlenmiştir.

\section{Veri Toplama Aracının Oluşturulması}

Veriler, nicel araştırma desenine uygun, sosyal medya araçlarıyla kullanılarak paylaşılabilen bir anket yardımıyla toplanmıştır. Ankette, toplam 72 tane beşli likert tipinde ölçek maddesi ve 6 tane demografik özellikli soru bulunmaktadır. Güvenilirliği ve geçerliği test edilmiş (Hsu, 2011) ölçekler kullanılmıştır. Bunlar; motivasyon ölçeği (9 madde; $\alpha=.78$ ), etkileşim ölçeği (10 madde; $\alpha=.70$ ), Türkçe konuşma rahatllğ ölçeği (7 madde; $\alpha=.91)$, öğretim elemanlarının algılanması ölçeği (12 madde; $\alpha=.81$ ), sosyokültürel uyum ölçeği (20 madde; $\alpha=.86$ ), akademik uyum ölçeğidir ( 8 madde; $\alpha=$.86). Ölçek maddelerinin Türkçeye uyarlanmasında Giresun Üniversitesi TÖMER biriminde görev yapan uzman eğitmenlerin görüşünden yararlanılmıştır. Yabancı uyruklu öğrencilerin anket sorularını daha kolay anlayabilmeleri sağlanarak araştırmanın güvenirliğinin artırılması hedeflenmiştir. Örneklemdekilerin demografik özellikler ise Tablo 1'de gösterilmiştir. Araştırma verisinin toplanması için kullanılan ölçme aracının iç tutarlılık güvenirliği, Cronbach alfa $(\alpha)$ değerinin hesaplanmasıyla belirlenmiştir. Araştırmada kullanılan ölçekler için hesaplanan Cronbach alfa $(\alpha)$ değerleri; motivasyon $\alpha=.888$, iletişim $\alpha=.865$, Türkçe konuşma rahatlığ $\alpha=.854$, öğretim elemanlarının algılanması $\alpha=.787$, sosyokültürel uyum $\alpha=.935$, akademik uyum $\alpha=.882$ ve ekonomik sorunlar $\alpha=$ .740 'tır. Alfa $(\alpha)$ değerlerinden çıkarılabilecek genel sonuç, ölçeklerin yüksek derecede güvenilir (Kalayc1, 2010) olduğudur.

\section{Evren ve Örneklem}

Araştırmanın evreni, Giresun Üniversitesinde öğrenim gören yabancı uyruklu öğrencilerdir. Araştırmanın yapıldığı tarihte Giresun Üniversitesindeki aktif yabancı uyruklu öğrenci sayısı 1010 'dur. Bu sayı aynı zamanda araştırmanın evrenini ifade etmektedir. Örneklem grubu, uygun örnekleme yöntemi (convenient sampling) yöntemi ile belirlenmiştir. Örneklemi 345 yabancı uyruklu öğrenci oluşturmaktadır. Örneklem büyüklüğü \%95 (0.05) güvenilirlik seviyesindedir ve sosyal bilimlerdeki nicel araştırmalar için asgari koşulu sağlamaktadır (Gürbüz ve Şahin, 2018, s. 131). Örneklemi oluşturan $\eta=345$ yabancı uyruklu öğrencinin demografik özellikleri Tablo 1'de verilmiştir.

Tablo 1

\begin{tabular}{|c|c|c|c|c|c|}
\hline Cinsiyet & $f$ & $\%$ & Aylık Ortalama Harcama & $f$ & $\%$ \\
\hline Kadın & 71 & 20,6 & 1000£’nin altında & 140 & 40,6 \\
\hline \multirow[t]{3}{*}{ Erkek } & 274 & 79,4 & 1000£-1500£ & 134 & 38,8 \\
\hline & & & 1501€-2000£ & 47 & 13,6 \\
\hline & & & 2000£ üzeri & 24 & 7,0 \\
\hline Yaş & $f$ & $\%$ & Konaklama Yerleri & $f$ & $\%$ \\
\hline 20 yaş altında & 109 & 31,6 & Kira & 185 & 53,6 \\
\hline 20-21 yaş & 112 & 32,5 & Özel Yurt & 65 & 18,8 \\
\hline
\end{tabular}




\begin{tabular}{|c|c|c|c|c|c|c|}
\hline $22-23$ yaș & 60 & 17,4 & Devlet Yurdu & & 48 & 13,9 \\
\hline $24-25$ yaş & 45 & 13,0 & Apart & & 37 & 10,7 \\
\hline 25 yaş üstü & 19 & 5,5 & Diğer & & 10 & 2,9 \\
\hline Türkiye'de Bulunma Süreleri & $f$ & $\%$ & Vatandaşlıkları & & $f$ & $\%$ \\
\hline 1 y1ldir & 115 & 33,3 & Azerbaycan & & 125 & 36,2 \\
\hline 2 yildır & 58 & 16,8 & Kazakistan & & 51 & 14,8 \\
\hline 3 yildır & 61 & 17,7 & Sudan & & 48 & 13,9 \\
\hline 4 yildir & 56 & 16,2 & Afganistan & & 28 & 8,1 \\
\hline 5 yildır & 30 & 8,7 & Türkmenistan & & 28 & 8,1 \\
\hline 5 yılın üzerinde & 25 & 7,2 & Diğer & & 65 & 18,8 \\
\hline Toplam & 345 & 100 & & Toplam & 345 & 100 \\
\hline
\end{tabular}

f: Frekans; \%: Yüzde; ‡: Türk Lirası

Giresun Üniversitesi’nde okuyan yabanc1 uyruklu öğrenciler daha çok Azerbaycan, Kazakistan, Türkmenistan, Sudan, Afganistan ülkelerinden gelmektedir. Vatandaşlıklar sütununda yer alan diğer ülkeler seçeneğinde ise Irak, Suriye, İran, Mısır, Yemek, Fas, Gine, Çat, Haiti gibi ülkeler yer almaktadır. Bu araştırmanın bulgularına göre yabancı uyruklu öğrenciler daha çok kirada oturmayı tercih etmektedir. Bu öğrencilerin barınma konusundaki ikinci önceliği ise özel yurtlardır. 2016 yılında Karabük Üniversitesinde yapılan araştırmaya göre ise özel yurt, yabancı uyruklu öğrencilerin birinci önceliğini oluşturmaktadır (Yıldıran vd., 2016). Bu sonuç, öğrencilerin ekonomik durumuyla şehir koşulları arasındaki ilişkiyle açıklanabilir. Bu araştırmanın bulguları demografik özellikler açısından önceki araştırmalarla benzerlik göstermiştir (Yıldıran vd., 2016). Öğrencilerin çoğunluğunu erkeklerin oluşturması, yaş aralığının 20 yaş altı ve 20-21 yaş aralığında en büyük oranı temsil etmesi gibi. Erkeklerin kadınlara göre yurt dışında üniversite eğitimi almaya teşvik edildiği ya da kendilerinin bu konuya daha eğilimli ve motive oldukları söylenebilir. Yaş dağılımı, yabancı uyruklu öğrencilerin genç yaşta Türkiye'de üniversite eğitime başlayabildiklerini göstermiştir.

\section{Verilerin Analizi}

İstatistiki yazılımı (SPSS 25) kullanılarak veriler analiz edilmiştir. İlk olarak verilerin normal dağılıp dağılmadığı analiz edilerek, hipotezlerin test edilmesinde hangi istatistiki yöntemlerin kullanılması gerektiği belirlenmiştir. Normallik testi bulguları Tablo 2'de sunulmuştur.

Tablo 2

Normallik Testi Sonuçları

\begin{tabular}{lccc}
\hline Değişkenler & Standart Sapma & $\begin{array}{c}\text { Çarpıklık } \\
\text { (Skewness) }\end{array}$ & $\begin{array}{c}\text { Basıklık } \\
\text { (Kurtosis) }\end{array}$ \\
\hline Motivasyon &, 0460 & $-1,159$ & 0,847 \\
Etkileşim &, 0413 & $-0,401$ & 0,342 \\
Türkçe Konuşma Rahatlığı &, 0541 & 0,138 & $-0,308$ \\
Öğretim Elemanı Algısı &, 0330 & 0,953 & 1,378 \\
Sosyokültürel uyum &, 0410 & 0,130 & $-0,660$ \\
Akademik Uyum &, 0428 & 0,349 & $-0,433$ \\
Ekonomik Sorunlar &, 0469 & $-0,366$ & $-0,222$ \\
\hline
\end{tabular}

Normallik testi sonucuna göre çarpıklık (Skewness) ve basıklık (Kurtosis) değerleri -1,5 ile $+1,5$ aralığında olduğundan veriler normal bir dağılım göstermektedir (Tabachnick ve Fidell, 2014). Dolayısıyla hipotezler, parametrik testler yardımıyla yapılmalıdır. Ölçeklerin güvenirliği Cronbach Alpha güvenilirlik katsayısıyla $(\alpha)$ hesaplanmıştır. Değişkenler arasındaki ilişkiler Pearson korelasyon katsayısıyla ortaya konulmuştur. Hipotezlerinin test edilmesinde çoklu doğrusal regresyon analizi yöntemiyle yapılmıştır. Regresyon analizlerinde Enter metodu kullanılmıştır. Tablo 3'te açımlayıcı faktör analizine ilişkin bulgular verilmektedir.

Tablo 3

Açımlayıcı Faktör Analizi Sonuçları

\begin{tabular}{lcccc} 
Motivasyon Ölçĕ̆i Maddeleri & Faktör Yükü & Özdeğer & Açıklanan Varyans (\%) & Cronbach Alpha (a) \\
\hline M7 & 0,853 & 4,861 & 54,014 & $0,899^{*}$ \\
M6 & 0,823 & &
\end{tabular}




$\begin{array}{ll}\text { M8 } & 0,807 \\ \text { M5 } & 0,803 \\ \text { M4 } & 0,789 \\ \text { M1 } & 0,719 \\ \text { M2 } & 0,680 \\ \text { M9 } & 0,622\end{array}$

KMO Dĕ̌eri $=0,822 ;$ Bartlett test $i=1998,166 ; p=0,000<0,05$

\begin{tabular}{|c|c|c|c|c|}
\hline Etkileşim Ölçeği Maddeleri & Faktör Yükü & Özdĕger & Açıklanan Varyans (\%) & Cronbach Alpha ( $\alpha$ ) \\
\hline E2 & 0,778 & \multirow{10}{*}{4,613} & \multirow{10}{*}{46,129} & \multirow{11}{*}{0,865} \\
\hline E9 & 0,763 & & & \\
\hline E7 & 0,760 & & & \\
\hline E10 & 0,718 & & & \\
\hline E6 & 0,711 & & & \\
\hline E4 & 0,654 & & & \\
\hline E3 & 0,626 & & & \\
\hline E8 & 0,621 & & & \\
\hline E5 & 0,560 & & & \\
\hline E1 & 0,556 & & & \\
\hline & $=0,817 ;$ Bartle & tt test $i=18$ & 806,$792 ; p=0,000<0,05$ & \\
\hline
\end{tabular}

\begin{tabular}{|c|c|c|c|c|}
\hline Türkçe Konuşma Rahatllğı Ölçeği Maddeleri & Faktör Yükü & Özdĕger & Açıklanan Varyans (\%) & Cronbach Alpha $(\alpha)$ \\
\hline TKR6 & 0,816 & & & \\
\hline TKR5 & 0,780 & & & \\
\hline TKR7 & 0,768 & & & \\
\hline TKR4 & 0,727 & 3,746 & 53,514 & 0,854 \\
\hline TKR2 & 0,713 & & & \\
\hline TKR3 & 0,693 & & & \\
\hline TKR1 & 0,603 & & & \\
\hline
\end{tabular}

\begin{tabular}{|c|c|c|c|c|}
\hline Ö̆̆gretim Elemanı Algısı Ölçeği Maddeleri & Faktör Yükü & $\ddot{O}$ zdĕger & Açılanan Varyans (\%) & Cronbach Alpha (a) \\
\hline ÖEA7 & 0,740 & & & \\
\hline ÖEA9 & 0,685 & & & \\
\hline ÖEA8 & 0,676 & & & \\
\hline ÖEA12 & 0,655 & 3,743 & 31,193 & $0,810^{*}$ \\
\hline ÖEA11 & 0,650 & & & \\
\hline ÖEA6 & 0,642 & & & \\
\hline ÖEA10 & 0,600 & & & \\
\hline \multicolumn{5}{|c|}{ KMO Değeri $=0,726 ;$ Bartlett test $i=1922,131 ; p=0,000<0,05$} \\
\hline
\end{tabular}

\begin{tabular}{|c|c|c|c|c|}
\hline Sosyokülttürel Uyum Ölçeği Maddeleri & Faktör Yükü & Özdĕger & Açıklanan Varyans (\%) & Cronbach Alpha (a) \\
\hline SKU18 & 0,771 & \multirow{20}{*}{9,034} & \multirow{20}{*}{45,172} & \multirow{20}{*}{0,935} \\
\hline SKU12 & 0,738 & & & \\
\hline SKU11 & 0,737 & & & \\
\hline SKU10 & 0,729 & & & \\
\hline SKU3 & 0,728 & & & \\
\hline SKU5 & 0,706 & & & \\
\hline SKU9 & 0,697 & & & \\
\hline SKU17 & 0,689 & & & \\
\hline SKU1 & 0,686 & & & \\
\hline SKU20 & 0,683 & & & \\
\hline SKU14 & 0,679 & & & \\
\hline SKU4 & 0,677 & & & \\
\hline SKU19 & 0,669 & & & \\
\hline SKU16 & 0,658 & & & \\
\hline SKU6 & 0,654 & & & \\
\hline SKU15 & 0,628 & & & \\
\hline SKU13 & 0,587 & & & \\
\hline SKU8 & 0,577 & & & \\
\hline SKU2 & 0,571 & & & \\
\hline \multirow[t]{2}{*}{ SKU7 } & 0,518 & & & \\
\hline & $=0,817 ;$ Bartle & tt testi $=4$ & 48,$624 ; p=0,000<0,05$ & \\
\hline
\end{tabular}




\begin{tabular}{|c|c|c|c|c|}
\hline Akademik Uyum Ölçeği Maddeleri & Faktör Yükü & $\ddot{O z}$ zdĕger & Açılanan Varyans (\%) & Cronbach Alpha ( $\alpha$ ) \\
\hline AU4 & 0,820 & \multirow{8}{*}{4,461} & \multirow{8}{*}{55,763} & \multirow{9}{*}{0,882} \\
\hline AU3 & 0,784 & & & \\
\hline AU8 & 0,767 & & & \\
\hline AU6 & 0,763 & & & \\
\hline AU2 & 0,761 & & & \\
\hline AU5 & 0,745 & & & \\
\hline AU7 & 0,690 & & & \\
\hline AU1 & 0,627 & & & \\
\hline \multicolumn{4}{|c|}{ KMO Değeri $=0,826 ;$ Bartlett test $i=1422,787 ; p=0,000<0,05$} & \\
\hline Ekonomik Sorunlar Ölçeği Maddeleri & Faktör Yükü & Özdĕger & Açıklanan Varyans (\%) & Cronbach Alpha (a) \\
\hline ES4 & 0,882 & & & \\
\hline ES3 & 0,819 & & & \\
\hline ES5 & 0,779 & 2,945 & 49,076 & $0,814 *$ \\
\hline ES6 & 0,667 & & & \\
\hline ES1 & 0,660 & & & \\
\hline \multicolumn{5}{|c|}{ KMO Değeri $=0,734 ;$ Bartlett test $i=711,231 ; p=0,000<0,05$} \\
\hline
\end{tabular}

*Faktör analizi sonrasında hesaplanan Cronbach Alpha $(\alpha)$ değerleridir.

Tablo 2'de açımlayıcı faktör analiziyle aralarında yüksek ilişkili değiş̧kenler setinin oluşturulması amaçlanmıştır. Veri setlerinin faktör analizi için uygun olup olmadığ 1 Kaiser-MeyerOlkin ve Barlett testleriyle belirlenmiştir. Analiz sırasında varimax faktör rotasyonu metodu kullanılmıştır. Özdeğer (Eigenvalues) istatistiğiyle faktör sayısı belirlenmiştir. Faktör yükü $<0,50$ olan ölçek maddeleri ölçekten çıkarılmıştır. $\mathrm{Bu}$ sayede faktörlerin güçlü maddelerden oluşması sağlanmıştır. Faktör analizi sonucunda bazı ölçeklerden; M3, ÖEA1, ÖEA2, ÖEA3, ÖEA4, ÖEA5, ES2 maddeleri çıkarılmıştır. Ölçek maddelerine ilişskin ifadeler Ek 1'de verilmiştir.

\section{Bulgular}

$\mathrm{Bu}$ bölümde, hipotezlerin test edilmesine yönelik gerçekleştirilen korelasyon ve regresyon analizi bulgularıyla ilgili bilgiler sunulmaktadır.

\section{Araștırma Hipotezlerinin Test Edilmesi}

$\mathrm{Bu}$ bölümde araştırmanın hipotezleri test edilmiştir. Hipotezlerin test edilmesi sırasında, korelasyon ve regresyon analizi yöntemi kullanılmıştır. Bulgular tablolar yardımıyla verilmiştir.

\section{Korelasyon Analizi Sonucu}

Tablo 4

Korelasyon Analizi Sonucu

\begin{tabular}{|c|c|c|c|c|c|c|c|c|c|}
\hline & Ort. & $S S$. & $S K U$ & $A U$ & $M$ & $E$ & $\ddot{O} E A$ & TKR & $E S$ \\
\hline$S K U$ & 3,6841 & 0,7618 & 1 & & & & & & \\
\hline$A U$ & 3,6594 & 0,7956 &, $712 * *$ & 1 & & & & & \\
\hline$M$ & 3,8583 & 0,8547 &, $556 * *$ &, $489 * *$ & 1 & & & & \\
\hline$E$ & 3,6116 & 0,7688 &, $554 * *$ &, $387 * *$ &, $607 * *$ & 1 & & & \\
\hline$\ddot{O E A}$ & 3,3176 & 0,6131 &, $452 * *$ &, $376 * *$ &, $367 * *$ &, $337 * *$ & 1 & & \\
\hline$T K R$ & 2,7143 & 1,0063 & $-0,044$ & $-0,072$ & 0,095 &, $140 * *$ & , 493** & 1 & \\
\hline$E S$ & 3,2874 & 0,8716 &, $124 *$ & $-0,056$ & $237 * *$ &, $272 * *$ & $433 * *$ &, $557 * *$ & 1 \\
\hline
\end{tabular}

Korelasyon analizi sonucunda, yabancı uyruklu öğrencilerin sosyokültürel uyumunun motivasyon, etkileşim, öğretim elemanı algısı ve ekonomik sorunlar ile anlamlı ve pozitif ilişkisinin olduğu görülmüş̧ür. Ancak, sosyokültürel uyumun Türkçe konuşma rahatlı̆̆ıyla anlamlı bir ilişkisi bulunamamıştır. Yabancı uyruklu öğrencilerin akademik uyumu ile motivasyon, etkileşim ve öğretim 
elemanı algısı arasında anlamlı ve pozitif ilişkiye ulaşılmıştır. Diğer taraftan akademik uyumun Türkçe konuşma rahatlığı ve ekonomik sorunlar ile anlamlı bir ilişkisinin olmadığı sonucuna varılmıştır.

\section{Regresyon Analizi Sonuçları}

Çoklu doğrusal regresyon analizi bulguları aşağıda tablolar yardımıyla gösterilmiştir.

Tablo 5

Sosyokültürel Uyum ile İlgili Regresyon Analizi Sonucu

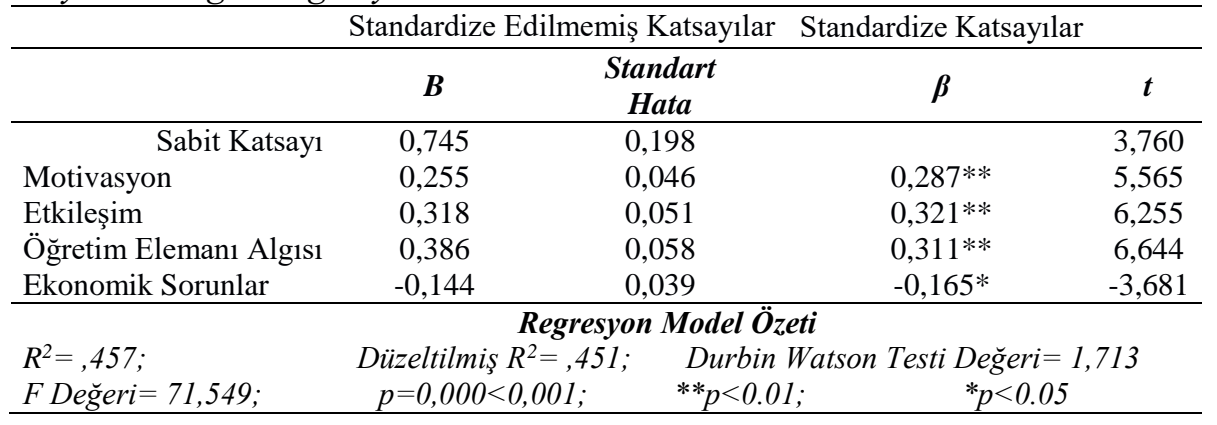

Sosyokültürel uyum bağımlı değişkenine ilişkin çoklu regresyon analizi sonuçları istatistiksel olarak anlamlıdır $[\mathrm{F}(4,340)=71,549 ; \mathrm{p}<0.001]$. Yabanc1 uyruklu öğrencilerin sosyokültürel uyumu üzerinde motivasyonun $\left(\beta=, 287^{* *}\right)$, etkileşimin $\left(\beta=, 321^{* *}\right)$ ve öğretim elemanı algısının $\left(\beta=, 311^{* *}\right)$ pozitif, ekonomik sorunların ise negatif yönlü $\left(\beta=,-, 165^{*}\right)$ anlamlı etkisinin olduğu bulunmuştur. Düzeltilmiş R2 değeri 0,451 olarak hesaplanmıştır. $\mathrm{Bu}$ değer, yabanc1 uyruklu öğrencilerin sosyokültürel uyumdaki \%45 oranındaki varyansı motivasyon, etkileşim, öğretim elemanı algısı ve ekonomik sorunların açıkladığını ortaya koymaktadır. Yukarıdaki regresyon analizi sonucu yabancı uyruklu öğrencilerin sosyokültürel uyumu üzerinde motivasyonun, etkileşimin, öğretim elemanı algısının ve ekonomik sorunların anlamlı katkısının olduğunu göstermiştir. Hipotez 1, Hipotez 3, Hipotez 5 ve Hipotez 9 kabul edilmiştir. Sosyokültürel uyum ile Türkçe konuşma rahatllğg 1 arasında anlamlı bir ilişki bulunamadığından Hipotez 7 reddedilmiştir.

Tablo 6

Akademik Uyum ile İlgili Regresyon Analizi Sonucu

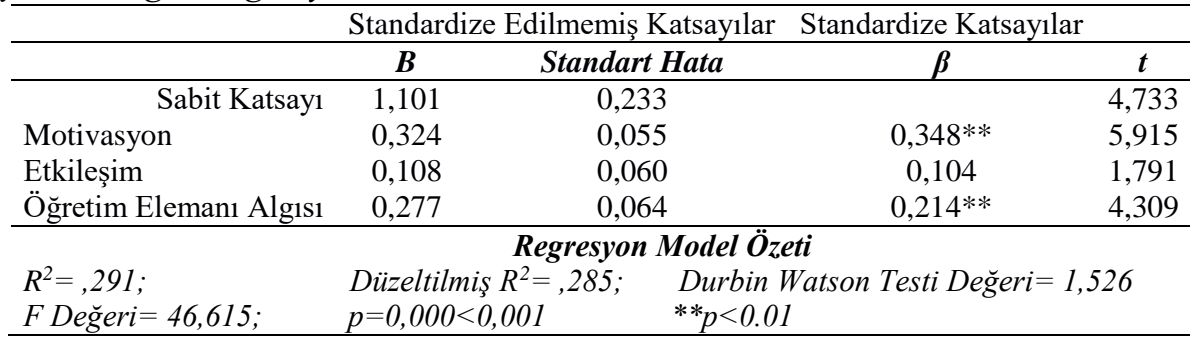

Akademik uyum bağımlı değişkeniyle ilgili çoklu regresyon analizi sonuçları regresyon modelinin istatistiksel olarak anlamlı olduğu görülmektedir $[\mathrm{F}(3,341)=46,615 ; \mathrm{p}<0.001]$. Düzeltilmiş R2 değeri $0,285^{\prime}$ tir. Bu nedenle yabancı uyruklu öğrencilerin akademik uyumundaki \%28,5'lik varyans bağımsız değişkenler tarafından açıklanmaktadır. Tablo 6' daki beta katsayıları incelendiğinde, yabanc1 uyruklu öğrencilerin akademik uyumunu açılamada motivasyonun $\left(\beta=, 348^{* *}\right)$ ve öğretim elemanı algısının $(\beta=, 214 * *)$ anlamlı katkısı vardır. Etkileşimin akademik uyumu açıklamada ise anlamlı bir katkısı bulunamamıştır $(\beta=, 104 ; p>0,05)$. Bu regresyon analiz sonucunda, Hipotez 2 ve Hipotez 6 kabul edilmiş, Hipotez 4 ise reddedilmiştir. Ayrıca korelasyon analizi sonucunda, akademik uyumun Türkçe konuşma rahatlığı ve ekonomik sorunlar ile arasında anlamlı bir ilişki bulunamadığından Hipotez 8 ve Hipotez 10 reddedilmiştir. 


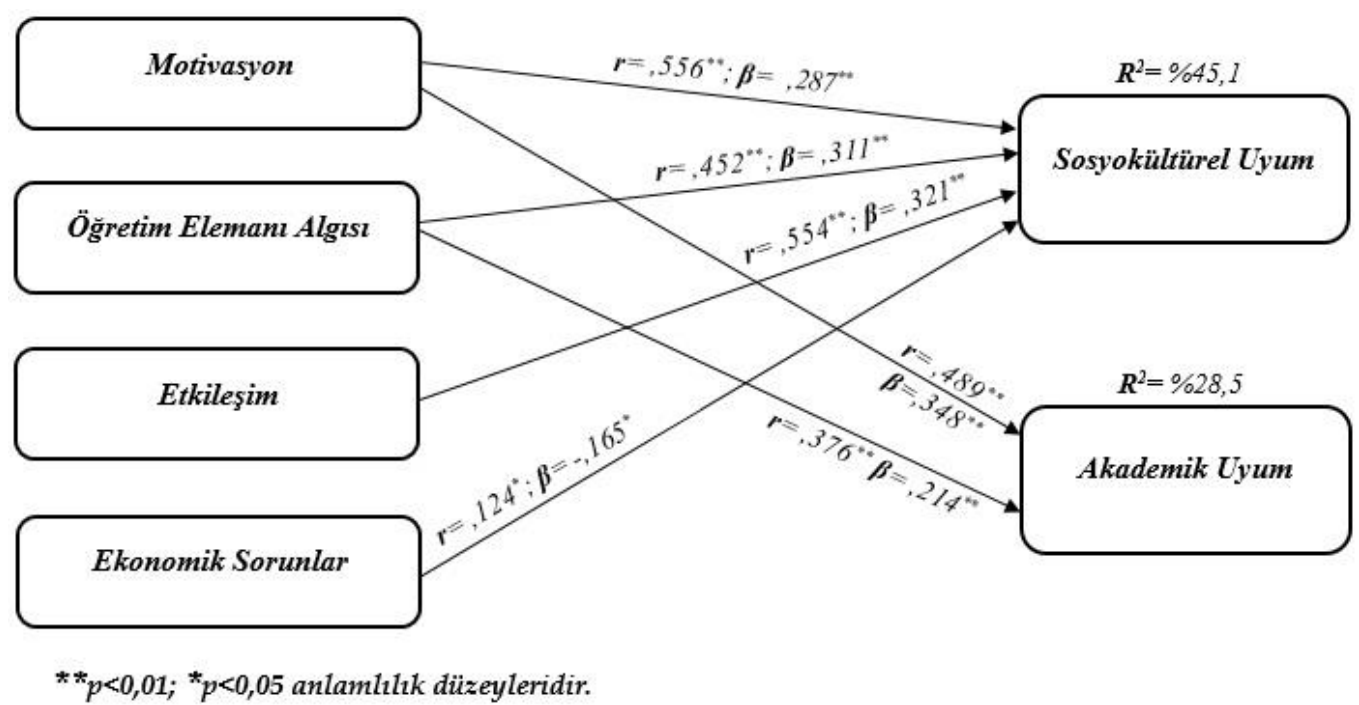

Şekil 1. Sonuç Modeli

\section{Sonuç, Tartıșma ve Öneriler}

$\mathrm{Bu}$ araştırmayla Giresun Üniversitesindeki yabancı uyruklu öğrencilerin sosyokültürel ve akademik uyumu üzerinde etkili olan faktörler belirlenmiştir. Araştırma sonucunda, yabancı uyruklu öğrencilerin sosyokültürel uyumu üzerinde motivasyonun, öğretim elemanı algısının, etkileşimin olumlu, ekonomik sorunların ise olumsuz etkisinin olduğu bulunmuştur. Başka bir ifadeyle bu araştırmaya göre yabancı uyruklu öğrencilerin motivasyonu, öğretim elemanı algıs1 ve etkileşimi öğrencilerin sosyokültürel uyumunu olumlu yönde etkilemektedir. Ekonomik sorunlar ise yabanc1 uyruklu öğrencilerin sosyokültürel uyumunu olumsuz yönde etkilemektedir. Motivasyon, etkileşim, öğretim elemanı algısı ve ekonomik sorunlar yabancı uyruklu öğrencilerin sosyokültürel uyumundaki \%45,1'lik bir varyansı açıklayabilmektedir. Diğer taraftan sosyokültürel uyum ile Türkçe konuşma rahatlığı arasında anlamlı bir ilişki bulunamamıştır. Böyle bir sonucun ortaya çıkmasında Türkiye'de yabanc1 uyruklu öğrencilere Türkiye'de TÖMER aracılı̆̆ 1 ile verilen Türkçe eğitimi gösterilebilir. Allaberdiyev'e (2007) göre, TÖMER sayesinde yabancı uyruklu öğrenciler Türkçeyi kullanarak daha iyi iletişim kurabilmekte ve daha uyumlu bir şekilde eğitimlerini sürdürebilmektedir. Bulguların, bu alanda yapılmış diğer çalışmaların bulgularıyla büyük ölçüde tutarlı olduğu söylenebilir (Hsu, 2011; Rüzgar, 2020; Saygın ve Hasta, 2018; Ward ve Kennedy, 1992; Yang, 2006). Hsu (2011) çalışmasında, yabancı uyruklu öğrencilerin sosyokültürel uyumu ile motivasyon, etkileşim, İngilizce konuşma rahatlığı, eğitmen algısı arasında anlamlı bir ilişkinin olduğu sonucuna ulaşmaktadır. Ward ve Kennedy (1993), yabancı uyruklu öğrencilerin sosyokültürel uyumunda dil yeterliliğinin, kültürel kimliğin ve mesafenin (kültürel bütünleşme-ayrılık) ve iletişim gibi birçok faktörün belirleyici olduğunu ve bu faktörlerin diğer öğrencilere göre yabanc1 uyruklu öğrencilerin sosyokültürel uyumunu daha fazla etkileyebildiğini ileri sürmektedir. Kumcağız ve diğerleri (2016), ekonomik sorunların kültürün tanınmasına ve geç öğrenilmesine neden olabileceğini ifade etmektedir. Allaberdiyev (2007) ise yabancı uyruklu öğrencilerin ekonomik durumları ile sosyal uyum düzeyleri arasında anlamlı bir farklılığın olmadığını belirtilmektedir. Allaberdiyev, aynı çalışmada yabancı uyruklu öğrencilerin dil, kültür gelenek ve görenek yönünden benzer olan bir ülkede eğitim almasının öğrencilerin sosyal uyumunu ve arkadaşlık kurabilmesini kolaylaştırdığını ileri sürmektedir. Türk Cumhuriyetlerinden gelen öğrencilerle Türk öğrenciler arasındaki ilişkilerde olduğu gibi.

Araştırmada kullanılan bağımsız değişkenlerin sosyokültürel uyumdaki varyansın \%45'ini açıklayabildiği sonucu, yabancı uyruklu öğrencilerin sosyokültürel uyumunda başka belirleyici faktörlerin de olduğunu göstermektedir. Dolayısıyla diğer faktörlerin belirlenmesine yönelik çalışmalar yapmanın ve belirlenen faktörlerin sosyokültürel uyum üzerinde etkisini ve önemini ortaya koymanın faydalı olacağı düşünülmektedir. Bu alanla ilgili çalışmalar, yabancı uyruklu öğrencilerin uyum sorunlarını anlamaya yardımcı olabilir. Literatürdeki boşluğun doldurmasına katkı sağlayabilir. 
$\mathrm{Bu}$ çalışmada, yabancı uyruklu öğrencilerin akademik uyumuyla ilgili bulgulara da yer verilmektedir. Bulgulara göre yabancı uyruklu öğrencilerin akademik uyumunda öğrencilerin motivasyonunun ve öğretim elemanı algısının belirleyici rolü bulunmaktadır. Motivasyon ve öğretim elemanı algısı yabanc1 uyruklu öğrencilerin akademik uyumunu olumlu bir şekilde etkilemektedir. Akademik uyumdaki \%28,5'lik bir varyansın motivasyon ve öğretim elemanı algısı tarafindan açıklanabildiğinin ortaya konulması yabancı uyruklu öğrencilerin akademik uyumunu açıklayabilen başka faktörlerin olduğunu göstermektedir. Ayrıca, akademik uyuma ilişkin regresyon analizi sonuçları etkileşimin, ekonomik sorunların ve Türkçe konuşma rahatlığının yabancı uyruklu öğrencilerin akademik uyumu üzerinde anlamlı bir etkisinin bulunmadığını göstermektedir. İlişki analizi sonucunda etkileşim ile akademik uyum arasında pozitif bir ilişki bulunmasına rağmen etkileşim değişkeninin akademik uyum üzerinde belirleyici bir rolünün bulunmadığ sonucuna ulaşılmaktadır. Akademik uyumla ilgili bulguların literatürdeki bulgularla kısmen tutarlı olduğu söylenebilir (Hsu, 2011; Kumcağız vd., 2016; Rüzgar, 2020). Hsu (2011), yetişkin yabancı uyruklu öğrenciler üzerinde yaptığı araştırmanın sonucunda akademik uyumu ile motivasyonu, etkileşimi, İngilizce konuşma rahatlı̆̆ ulaşmıştır. Türkiye'de gerçekleştirilen bu çalışmanın bulguları Hsu (2011) ile kısmen benzerlik göstermektedir. Araştırma bulgularının farklılık göstermesi bazı nedenlere dayandırılabilir. Giresun Üniversitesindeki yabancı uyruklu öğrencilerin büyük çoğunluğunu Türkiye ile ortak kültürlere sahip ülkelerin öğrencileri oluşturmaktadır. Yabancı uyruklu öğrencilerin uyruğu ile eğitim alınan ülke arasında sosyal ve kültürel açıdan bir yakınlığın bulunması araştırma sonuçlarının farklılaşmasına neden olabilir. Çünkü Giresun Üniversitesindeki yabancı uyruklu öğrencilerin çoğunluğu Türkiye hatta Türkiye'nin diğer illerine göre Giresun'a daha yakın ülke ve coğrafyadan gelmektedir.

Alan yazında yabancı uyruklu öğrencilerin akademik ve sosyal uyumu konusuyla ilişkili başka çalışmalar da bulunmaktadır. Özçetin'e (2013) göre yabancı uyruklu öğrencilerin gelir durumu, özellikle kültürel faaliyetlere katılım ve sosyal uyum açısından önemli bir faktördür. Özçetin (2013) çalışmasında ekonomik sorunlar ile akademik uyum arasında herhangi bir ilişkinin olmadığını ifade etmektedir. Bazı araştırmacılar yabancı uyruklu öğrencilerin akademik uyum ile dersi anlama düzeyleri arasında olumlu bir ilişkinin olduğunu belirtmektedir. Özkan ve Acar Güvendir (2015), akademik uyumun yabancı uyruklu öğrencilerin başarısıyla ilişkili bir durumun olduğunu vurgulamaktadır. Kıroğlu ve diğerlerine (2010) göre yabancı uyruklu öğrenciler, Türkiye'de sosyokültürel uyum konusunda bir sorun yaşamamaktadır. Çünkü, Türkiye'deki yabancı uyruklu öğrenciler genellikle Türkiye ile tarihsel ve kültürel bağı bulunan ülkelerden gelmektedir. Dolayısıyla bu öğrenciler, Türklerle iyi arkadaşlık kurarak uyumları kolaylaşmaktadır.

$\mathrm{Bu}$ çalışmanın ve literatürdeki araştırmanın bulgularından yola çıkılarak bazı önerilerde bulunulabilir. $\mathrm{Bu}$ araştırmanın yapıldığı Giresun Üniversitesindeki yabancı uyruklu öğrencilerin çoğunluğunu Türki Cumhuriyetlerden gelen yabancı öğrenciler oluşturmaktadır. Türki Cumhuriyetlerden gelen öğrencilerin Türkiye ile tarihsel ve kültürel bağlarının bulunması öğrencilerin Türkiye'de, Giresun'da veya Giresun Üniversitesindeki sosyokültürel uyumunu kolaylaştırmış olabilir. Yabancı uyruklu öğrencilere sahip üniversitelerin özellikle akademik personelinin yabancı uyruklu öğrencilerle daha fazla iletişimde ve etkileşimde bulunması öğrencilerin akademik ve sosyal uyumuna katkı sağlayabilir. Üniversitenin akademik ve idari personeli öğrencilerin sosyokültürel ve akademik uyumunu kolaylaşabilir, motivasyonlarını ve akademik başarısı artırılabilir.

$\mathrm{Bu}$ araştırmada, yabanc1 uyruklu üniversite öğrencilerinin yaşadığı ekonomik sorunların sosyokültürel uyumu olumsuz etkilediği tespit edilmiştir. Dolayısıyla yabancı uyruklu öğrencilerin yardım kuruluşlarınca ekonomik olarak desteklenmesiyle öğrencilerin ekonomik sorunlarını kısmen de olsa giderilebilir. Ayrıca, üniversiteler, kamu kurumları, diğer dernek ve vakıflar, vb. örgütsel kuruluşlar tarafindan da bu öğrenciler ekonomik olarak desteklenebilmelidir. Böylece öğrencilerin sosyokültürel uyumu daha kolay ve hızlı bir şekilde gerçekleştirilebilir. Araştırmanın bulgularına göre yabanc1 uyruklu öğrencilerin sosyokültürel ve akademik uyumunu kolaylaştırmak için üniversite eğitimi aldıkları ülkedeki veya şehirdeki, eğitim gördükleri eğitim kurumundaki iletişimi ve etkileşimi güçlendirilmelidir. Yabancı uyruklu öğrencilerin diğer insanlarla iletişimini ve etkileşimi desteklemek, 
yerli ve yabancı bireylerle öğrencilerle etkileşimde bulunmalarını sağlamak, eğitim başarına olumlu yansiyabilir.

$\mathrm{Bu}$ çalışma, öğrencilerin akademik ve sosyokültürel uyum üzerinde başka belirleyicilerin olduğunu göstermektedir. Türkiye'deki yabancı uyruklu öğrencilerin akademik ve sosyokültürel uyumu üzerinde etkili olan diğer faktörlerin belirlenmesine yönelik başka çalışmalar yapılabilir. Yabancı uyruklu öğrencilerin akademik ve sosyokültürel uyumu, öğretim elemanı algısı ve akademik başarısı arasındaki ilişki bir model ile test edilebilir. Yabancı uyruklu öğrencilerin akademik ve sosyokültürel uyum düzeyleri öğrencilerin ülkelerine ve demografik özelliklerine göre incelenebilir. Örneğin, akademik ve sosyokültürel uyum ile öğrencilerin uyruğu arasındaki ilişki araştırılabilir. Bu araştırmanın bulgularından yola çıkılarak akademik ve sosyokültürel uyum üzerinde etkisi tespit edilen değişkenler ile öğrencilerin uyruğu arasında bir ilişkinin olup olmadığ araştırma konusu yapilabilir.

\section{Yazarların Katkı Oranı}

Bu makaleye birinci yazarın \%50, ikinci yazarın $\% 50$ oranında katkısı vardır.

\section{Çıkar Çatışması}

$\mathrm{Bu}$ çalışmada çıkar çatışması teşkil edebilecek bir durum yoktur.

\section{Kaynaklar}

Allaberdiyev, P. (2007). Türk Cumhuriyetlerinden Türkiye’ye yükseköğrenim görmeye gelen ögrencilerin uyum düzeylerinin incelenmesi. Yüksek lisans tezi. Gazi Üniversitesi, Eğitim Bilimleri Enstitüsü, Ankara.

Başaran Alagöz, S. ve Geçkil, T. (2017). Yabancı uyruklu üniversite öğrencilerinin sorunlarının incelenmesi: Konya ili örneği. Anadolu Hemşirelik ve Sağllk Bilimleri Dergisi, 20(4), 279285.

Berry, J., ve Sabatier, C. (2010). Acculturation, discrimination, and adaptation among second generation immigrant youth in Montreal and Paris. International Journal of Intercultural Relations, 34, 191-207.

Berry, J., Poortinga, Y., Breugelmans, S., Chasiotis, A. and Sam, D. (2011). Cross cultural psychology: research and applications. Cambridge: Cambridge University Press.

Cüceloğlu, D. (2005). İnsan ve davranışı - psikolojinin temel kavramları. İstanbul: Remzi Kitabevi.

Dilekmen, M. ve Ada, Ş. (2005). Ögrenmede güdülenme. Kazım Karabekir Eğitim Fakültesi Dergisi, $11,113-123$.

Gizir, S. (2007). Üniversitelerde örgüt kültürü ve örgüt-içi iletişim üzerine bir derleme çalışması. Kuram ve Uygulamada Eğitim Yönetimi, 50, 247-268.

Güngör, D. (2014). İkinci kuşak Avrupalı Türklerde psikolojik entegrasyon ve uyum: çift boyutlu kültürleşme temelinde karşılaştırmalı bir derleme. Türk Psikoloji Yazıları, 17(34), 16-31.

Gürbüz, S., ve Şahin, F. (2018). Sosyal bilimlerde araştırma yöntemleri felsefe-yöntem-analiz. Ankara: Seçkin Yayıncılık. 
Hsu, C.-H. (2011). Factors influencing international students' academic and sociocultural transition in an increasingly globalized society. Hattiesburg, USA: The University of Southern Mississippi.

Kalaycı, Ş. (2010). SPSS uygulamalı çok değişkenli istatistik teknikleri. Ankara: Asil Yayın Dağıtım.

Kara, M. A. (2017). Göç yazıları. Ankara: Kırmızı Çatı.

Kıroğlu, K., Kesten, A. ve Elma, C. (2010). Türkiye'de öğrenim gören yabancı uyruklu lisans öğrencilerinin sosyokültürel ve ekonomik sorunları. Mersin Üniversitesi Eğitim Fakültesi Dergisi, 6(2), 26-39.

Kumcağız, H., Dadashzadeh, R. ve Alakuş, K. (2016). Ondokuz Mayıs Üniversitesi'ndeki yabanc1 uyruklu öğrencilerin sınıf düzeylerine göre yaşadıkları sorunlar. Ondokuz Mayıs Üniversitesi Eğitim Fakültesi Dergisi, 35(2), 37-50.

Mete, F. (2015). Dil ve yabancı ikinci dil eğitimi kavramları. A. Sarıçoban (Ed.), Yabancı dil olarak Türkçe ögretimi metodolojisi içinde (ss. 158-190). Ankara: Anı Yayınları.

Özçetin, S. (2013). Yükseköğrenim gören yabancı uyruklu öğrencilerin sosyal uyumlarını etkileyen etmenler. Yüksek lisans tezi. Hacettepe Üniversitesi, Sosyal Bilimler Enstitüsü, Ankara.

Özdemir, İ. (2011). Kültürlerarası İletişimin Önemi. Folklor/Edebiyat Dergisi, 17(66), 29-38.

Özkan, G. ve Acar Güvendir, M. (2015). Uluslararası öğrencilerin yaşam durumları: Kırklareli ve Trakya üniversiteleri örneği. Abant İzzet Baysal Üniversitesi Eğitim Fakültesi Dergisi, 15(1), 174-190.

Rüzgar, M. (2020). Yurt dışında yükseköğrenim gören Türk öğrenciler üzerine bir araştırma. Yüksekögrretim ve Bilim Dergisi, 10(1), 193-204.

Saygın, S. ve Hasta, D. (2018). Göç, Kültürleşme ve uyum. Psikiyatride Güncel Yaklaşımlar, 10(3), 312-333.

Şeker, B. D. ve Akman, E. (2016). Uluslararası öğrencilerin psikolojik ve sosyokültürel süreçleri. Çukurova Medical Journal, 41(3), 504-514.

Tabachnick, B. and Fidell, L. (2014). Using multivariate statistics. Boston: Pearson.

Temel Eğinli, A. (2011). Kültürlerarası yeterliliğin kazanılmasında kültürel farklılık eğitimlerinin önemi. Öneri, 9(35), 215-227.

Ünal, K., Taşkaya, S. ve Ersoy, G. (2018). Suriyeli göçmenlerin yabancı dil olarak Türkçe öğrenirken karş1laştıkları sorunlar ve çözüm önerileri. Ahi Evran Üniversitesi Sosyal Bilimler Enstitüsü Dergisi, 4(2), 134-149.

Üstün, F. ve Büyükbaş, Ş. (2020). Uyum performansı ölçeğinin Türkçe uyarlaması: Geçerlik ve güvenirlik çalışması. Ahi Evran Üniversitesi Sosyal Bilimler Enstitüsü Dergisi, 6(2), 637-656.

Ward, C. and Kennedy, A. (1992). Locus of control, mood disturbance, and social difficulty during cross-cultural transitions. International Journal of Intercultural Relations, 16(2), 175-194.

Ward, C. and Kennedy, A. (1993). Psychological and socio-cultural adjustment during cross-cultural transitions: A comparison of secondary students overseas and at home. International Journal of Psychology, 28(2),129-147. 
Ward, C. (1996). Acculturation. D. Landis ve R. Bhagat (Ed.), Handbook of Intercultural Training (p.124-147). Newbury Park, CA: Sage.

Ward, C. ve Rana-Deuba, A. (2000). Home and host culture infuences on sojourner adjustment. International Journal of Intercultural Relations, 24, 291-306.

Yang, H. (2006). Understanding experiences of being a Chinese overseas student in the Ways of Knowing and Doing (p. 246-254). University of Birmingham.

Yıldıran, C., Özkan, D. ve Büyükyılmaz, O. (2016). Yabanc1 uyruklu lisans öğrencilerinin durum analizi: Karabük Üniversitesi. Uluslararası Bilimsel Araştırmalar Dergisi, 1(1), 20-34. 


\section{Extended Abstract}

\section{Introduction}

With the globalization process, migration movements are increasing day by day and mobility between countries is accelerating. Turkey, especially after the 1980 "country of immigration" it has become. Turkey has become the state target country for immigrants (Kara, 2017). The developments in the field of education in Turkey has attracted foreign individuals into the country. For example, Giresun University has over a thousand foreign students. This number is increasing day by day. These developments as well as other countries have made significant foreign nationality student to investigate the problems of living in Turkey. Research on this subject have mostly focused on identifying the problems experienced by foreign students.

Researches have been conducted in the literature to determine the factors affecting the academic and sociocultural adaptation of foreign national students. Researches conducted in Turkey and other countries, generally, have sought to identify the problems they experienced the education of foreign national university students. According to research foreign national university students in Turkey generally; It is faced with sociocultural and economic problems such as communication, human relations, economic problems, housing, homesickness, food, clothing, traditions and customs. These problems effect the academic life of foreign national university students (Başaran Alagöz and Geçkil, 2017; Güngör, 2014; Kıroğlu, Kesten and Elma, 2010; Kumcağız, Dadashzadeh and Alakuş, 2016; Rüzgar, 2020; Özkan and Acar Güvendir, 2015; Saygın and Hasta, 2018; Yıldıran, Özkan and Büyükyılmaz, 2016). Similar results have been obtained in researches conducted in other countries. (Berry and Sabatier, 2010; Berry, Poortinga, Breugelmans, Chasiotis and Sam, 2011; Hsu, 2011; Ward and Kennedy, 1992; Ward and Kennedy, 1993; Yang, 2006). Hsu (2011) investigated this issue at an international level in a fairly wide scope. Hsu, addressed the factors associated with the sociocultural and academic adjustment of foreign national university students. Concluded that there are significant relationships between comfort with oral English, interaction, motivation, online support and perception of instructors and academic and sociocultural adaptation.

Previous studies were used to determine the variables used in this study. Thus, foreign students study in Turkey and in other countries are often discussed the problems faced. These; sociocultural adaptation, academic adaptation, instructor perception, motivation, interaction, economic problems, Turkish speaking comfort.

Sociocultural adaptation is considered to be the adoption of certain features of the mainstream culture by individuals who are culturally minorities and the use of them appropriately for their new lives (Berry, Poortinga, Breugelmans, Chasiotis and Sam, 2011). Academic adaptation is an adaptation problem related to the education and success of foreign students at the university. One of the problems experienced by foreign students is their level of understanding of the lesson (Özkan and Acar Güvendir, 2015; Yang, 2006). Motivation is explained as "a general concept that includes desires, wish, needs, impulses and interests" (Cüceloğlu, 2005). Therefore, motivation can be considered as an important factor affecting foreign nationality students behaviors and attitudes throughout the education process (Hsu, 2011). The Turkish speaking comfort is a phenomenon related to how comfortable students with foreign nationality feel themselves when speaking Turkish. Economic problems are among the basic problems of individual, organizational and sociocultural environment. University students are one of those who feel the individual effects of these problems. The concept of economic problem is a national and international dimension for university students. Especially, it is a factor that can affect the education and training processes of foreign nationality students directly or indirectly (Özkan and Acar Güvendir, 2015). Interaction is a communicative result. The nature of the communication can determine the strength of the interaction. Negativity in communication causes a decrease in academic achievement and a deficiency in subjects such as asking questions of foreign nationality students (Kumcağız, Dadashzadeh and Alakuş, 2016). In this study, the perception of the lecturer expresses how the academician teaching at the university's approach to her lesson is perceived by foreign students. 
The aim of this study is to reveal the effect of national and organizational culture on the sociocultural and academic adaptation of foreign university students.

Is it cultural and organizational characteristics of universities in Turkey will affect the adaptation of foreign nationality students?

What are the factors affecting the socio-cultural and academic adaptation of foreign nationality university students?

\section{Method}

In this section, information about the creation of the data collection tool, the population and the sample, the data obtained as a result of the field study and the analysis of the data are explained.

The study is in quantitative research design. The data of the research were collected by the online survey method application between April 24, 2020 and May 18, 2020. The online survey includes a total of 72 five-point Likert-type scale items and 6 demographic questions. The sample of the study consisted 345 foreign nationality students who answered the questionnaire. The number of active foreign national students at Giresun University at the time of the research is 1010. The data were analyzed through an internationally accepted statistical software. First, normality test, reliability and factor analysis were performed on the data. The scales and items used in the research are as follows: motivation scale ( 9 items), interaction scale (10 items), comfort of speaking Turkish scale (7 items), instructor perception scale (12 items), sociocultural adaptation scale (20 items), and academic adaptation scale (8 items), economic problems scale (6 items). The internal consistency reliability of the measuring tool was calculated with the Cronbach alpha $(\alpha)$ coefficient. Cronbach's alpha $(\alpha)$ values calculated for the scales; motivation $\alpha=.888$, interaction $\alpha=.865$, comfort of speaking Turkish $\alpha=$ .854 , perception of instructors $\alpha=.787$, sociocultural adaptation $\alpha=.935$, academic adaptation $\alpha=$ .882 , and economic problems $\alpha=.740$. Scale items with a factor load of $<0.50$ were removed from the scale. Hypotheses have been tested using correlation and regression analysis method.

\section{Conclusion, Discussion and Recommendations}

As a result of the research, it was found that motivation, interaction, perception of instructor and economic problems are effective on the sociocultural compatibility of foreign nationality students. On the other hand, the effect of motivation and the perception of the instructor on academic adaptation was determined. The comfort of speaking Turkish did not have an effect in both socio cultural and academic adaptation. According to the results of this research, motivation and instructor perception are important for the sociocultural and academic adaptation of foreign nationality students. In addition, interaction and economic problems are important in sociocultural adaptation.

The results of the study, Turkey and the results of the research are largely similar in other country (Allaberdiyev, 2007; Hsu, 2011; Kıroğlu et al., 2010; Özkan and Acar Güvendir, 2015). However, differences were observed in terms of the relationship and effect between the variables.

In this context, universities should provide support to foreign students to ensure their satisfaction during their education. Academic staff of universities should communicate positively at both institutional and individual levels that will contribute to the academic and social cohesion of foreign students and should be able to motivate these students. Thus, the academic success of students can be increased. Students' sociocultural adaptation problem can be eliminated in a shorter time. 
Ek1

Anket Formu

Motivasyon Ölçeği: Neden yurtdışında okumaya karar verdiğinizi bilmek istiyoruz.

M1 Kariyer ve yaşam imkânlarımı iyileştirmek istediğim için yurtdışında okumayı istedim.

M2 İyi bir eğitim almak için yurt dıșında okumak istedim.

M3* Yabancı dilde uzmanlaşmak istediğim için yurtdışında okumayı istedim.

M4 Yabancı bir üniversite diploması benim için iyi bir iş imkânı yaratacağından yurtdışında okumayı istedim.

M5 Türkiye geldim çünkü Türkiye benim için önemlidir.

M6 Türkiye'ye, gerçekten istediğim için geldim.

M7 Türkiye'ye hayatımdaki hedeflerimden biri olduğu için geldim.

M8 Türkiye'ye, bende kişisel değeri büyük olduğu için geldim.

M9 Türkiye'ye elime değerli bir firsat geçtiği için geldim.

Etkileşim Ölçeği: Türklerle ne sıklıkla etkileşim kurduğunuzu bilmek istiyoruz.

$\begin{array}{ll}\text { E1 } & \text { Türklerin düzenlediği etkinliklere katılıyorum. } \\ \text { E2 } & \text { Türk arkadaşlarımla ve tanıdıklarla yüz yüze (yakın) iletişim kuruyorum. }\end{array}$

E3 Çoğunluğunu Türklerin oluşturduğu halka açık organizasyonlara ve özel eğlencelere katılıyorum.

E4 Türk arkadaşlarımı gittiğim etkinliklere davet ediyorum.

E5 Herhangi bir problemle karşılaştığımda Türk arkadaşlardan ya da tanıdıklardan yardım istiyorum.

E6 Kendi ülkemden insanların düzenlediği etkinliklere katılırım.

E7 Kendi ülkemden arkadaşlarla ve tanıdıklarla yüz yüze (karşılıklı) iletişim kuruyorum.

E8 Çoğunluğunu ülkemin insanlarının oluşturduğu organizasyonlara ve özel etkinliklere katılırım.

E9 Kendi ülkemden arkadaşları benimle etkinliklere katılmaya davet ediyorum.

E10 Kendi ülkemden arkadaşlarımdan veya tanıdıklarımdan yardımcı olmalarını istiyorum.

Türkçe Konușma Rahatlı̆̆ı Ölçeği: Türkçe konuşulurken kendinizi ne kadar rahat hissettiğinizi bilmek istiyoruz.

TKR1 Derste, çağırılacağımı bildiğim zaman endişeleniyorum.

TKR2 Türkçe konusunda diğer öğrencilerin benden daha iyi olduğunu düşünüyorum.

TKR3 Sinıfta kendi isteğimle cevaplar vermekten utanıyorum.

TKR4 Derste, söz hakkı verildiğinde heyecanlandığımı hissediyorum.

TKR5 Türkçe konuştuğumda diğer öğrencilerin bana güleceğinden korkuyorum.

TKR6 Diğer öğrencilerin Türkçeyi her zaman benden daha iyi konuşabildiğini hissediyorum.

TKR7 Öğretmenim Türkçe konuştuğunda, söylediklerini doğru anlamamaktan korkuyorum.

Ö̆̆retim Elemanlarının Algılanması Öıçeği: Öğretim elemanlarının uluslararası ögrencilere, yani size verdiği desteğe ya da ögretim elemanlarının destek eksikliğine ilişkin algılarınızı bilmek istiyoruz.

ÖEA1* Öğretim elemanları, dersle ilgili olmayan materyalleri gönderirler.

ÖEA2* Öğretim elemanları, çalışacağım meslekle ilgili bilgiler yerine teorik bilgiler verir.

ÖEA3* Öğretim elemanları, öğrencilerin ödevlerini eksizsiz yapabilecekleri bilgiyi vermemektedir.

ÖEA4* Öğretim elemanları, yapmam gerekenleri anlayabileceğim şekilde planlar.

ÖEA5* Öğretim elemanları, teslim edilen ödevler hakkında geri bildirimde bulunmaz.

ÖEA6 Öğretim elemanları, öğrencilerin başarılı (kaliteli) çalışmalarına veya yorumlarına övgüde bulunur.

ÖEA7 Öğretim elemanları, öğrencilerin, üzerinde durulan konu hakkındaki farklı yorumlarını önemser.

ÖEA8 Öğretim elemanları, ders esnasında öğrencilere fikirlerini söylemeye teşvik eden sorular sorar.

ÖEA9 Öğretim elemanları, öğrencilerin aralarında konuştuğu konular hakkında fikrini söyler.

ÖEA10 Öğretim elemanları, dersin içeriğinden daha çok öğrencilerin başka şeyler hakkındaki sorularını cevaplar.

ÖEA11 Öğretim elemanları, öğrencilerin anlamalarına yardımcı olması için tecrübelerinden örnekler verir.

ÖEA12 Öğretim elemanları, sınıfta ders işlerken esprilidir.

Sosyokültürel Uyum Ölçeği: Türkiye'de, üniversitede eğitim aldığınız süre boyunca hayata uyum sağlamanızın zorluğunu bilmek istiyoruz.

\begin{tabular}{ll}
\hline SKU1 & Türkiye'deki halkın kültürünü anlamak kolay oldu. \\
SKU2 & Türkiye'deki halkın dünya görüş̈nü anlamak kolay oldu. \\
SKU3 & Türk gibi davranabilmem kolay oldu. \\
SKU4 & Türkiye'deki kültürel farklılıkları anlamak kolay oldu. \\
SKU5 & Türk kültürüne yerel bir bakış açısı getirmek kolay oldu. \\
SKU6 & Türklerle arkadaş olmak kolaydır. \\
SKU7 & Ülkem ile Türk kültürü arasındaki farkı kolaylıkla görebiliyorum. \\
SKU8 & Ailevi problemlerimle baş edebiliyorum. \\
SKU9 & Türklerin beni anlaması kolay oldu. \\
SKU10 & Farklı etnik gruplardan insanlarla iletişim kurmak kolay oldu. \\
SKU11 & Türkiye'de karş1 cinsiyettekilerle etkileşim kurabilmem kolay oldu. \\
SKU12 & Yerel düzeyde siyasi sistemi anlamak kolay oldu. \\
SKU13 & Okuduğum yerde adresleri kolayca bulabiliyorum. \\
SKU14 & Yetkili kişilerle kolay iletişim kurabiliyorum. \\
SKU15 & İnsanların bana bakışlarına alışmam kolay oldu. \\
SKU16 & Hoşlanmadığım insanlarla başa çıabilmem kolay oldu. \\
SKU17 & Tatmin olmadığım hizmetlerle başa çıkmak kolay oldu. \\
SKU18 & Bürokrasi ile başa ç1kabilmem kolay oldu. \\
SKU19 & Yaşamın hızıyla kolayca ayak uydurabiliyorum (baş edebiliyorum).
\end{tabular}


SKU20 Sevdiğim yiyecekleri kolayca bulabildim.

Akademik Uyum Ölçeği: Türkiye'de, üniversitedeki akademik performansınızla ilgili algılarınızı bilmek istiyoruz.

AU1

AU2

AU3

AU4

AU5

AU6

AU7

AU8

Ekonon

\section{ES1}

ES2*

ES3

ES4

ES5

ES6

Not: (*); faktör yükü<0,50 ölçek maddeleridir.

Ulaşım ücreti çok pahalıdır.
Akademik performansımın seviyesinden memnunum.

Akademik çalışmalarımda ortalama öğrenciler kadar yetenekliyim.

Üniversitede, karşılaşabileceğim zorluklarla başa çıkabileceğimden oldukça eminim.

Şimdiye kadar, bölümdeki deneyimlerim beklentilerimi karşıladi.

Fakültedeki ve diğer bölümlerdeki öğrencilerle iletişimim iyidir.

Derslerime odaklanmakta (konsantre) sorun yaşamıyorum.

$\mathrm{Bu}$ üniversitede olmaktan memnunum.

Sınav sonuçlarımın bu bölümdeki akademik yeteneğimi doğru bir şekilde gösterdiğini hissediyorum.

Ailemden gelen parayla geçinmekte zorlanıyorum.

Valilik, belediye gibi kurumlar şehir içi ulaşım, yemek bursu gibi imkânlar sunmaktadır.

Yabancı uyruklu öğrenci için bu şehir çok pahalıdır.

Ekonomik sıkıntılar yaşamaktayım.

Türkiye vatandașı olmadığım için burs alamıyorum. 